Article

\title{
Confession and Hope: Ekklesia's Task in the Global Emergency
}

\section{Timothy Gorringe}

Department of Religion and Theology, University of Exeter, Exeter EX4 4PY, UK; t.j.gorringe@exeter.ac.uk

Received: 9 December 2019; Accepted: 17 February 2020; Published: 20 February 2020

\begin{abstract}
Humanity is currently faced with deadly dangers that could bring about the breakdown of civilization, and even the end of human life on earth in short order. The Marxist and Green thinker Rudolf Bahro spoke of a 'logic of salvation', which involved a return to the idea of God. Ekklesia arose as a witness to such a logic of salvation. It can be understood as a social movement, that sketches out a prefigurative politics that can then be realised. The contemporary church needs to recover this understanding, adopting climate change as a confessional issue that defines its common life. This could be part of a practical logic of salvation.
\end{abstract}

Keywords: global emergency; consumerism; neo-liberalism; ekklesia; confession; strength and weakness

\section{The Four Horsemen}

Doubtless every generation has its own version of the four horsemen of Revelation 6, and they have been grim enough over the centuries, but never as genuinely apocalyptic, in the popular sense, as today. Today's four horsemen-overpopulation, resource depletion, loss of biodiversity and climate change-could each separately mean civilisational collapse and put together they could mean the end of human life on earth. ${ }^{1}$

The first issue is population, which has more than doubled since 1961 to getting on for 8 billion. The UN predicts it will plateau at 11 billion at the end of the century but this cannot be guaranteed. The assumption is that women's education, and the availability of contraception, will stabilize numbers but, as Stephen Emmot points out, both of these have been available in Niger for years, and the average birth rate is still seven children per woman. In China and Hungary larger families are officially promoted. If the current rate of global reproduction continues, there will not be eleven billion, but twenty eight billion human beings by the end of the century (Emmott 2013). While one sixth of the present world population still live in absolute poverty it remains the case that, as the Baltimore economist Herman Daly has been arguing for half a century, huge numbers mean huge impacts. Emmott argues that the pressures this size of population will generate can only end in complete collapse, in which the earth will become uninhabitable.

Population impacts are intensified by the dominant economic model, neo-liberalism, which looks for more and more growth, ignoring the warnings of the 'Limits to Growth' report of fifty years ago. The mission of the World Bank is to put an end to poverty, which is admirable, but the subtext is that the whole world should live like the United States-which would require five planets, and indeed more if absolute numbers keep growing. One of the results of this version of 'economy' (actually, an anti-economy as Wendell Berry in particular has argued) is a soaring gap between rich and poor all over

1 In this section I am summarising an argument set out at length in my book The World Made Otherwise (Gorringe 2018). 
the world. Today inequality is driven not primarily by inherited wealth but by salary differentials. ${ }^{2}$ Some CEOs earn more than a thousand times what their lowest paid employees earn. The French economist Thomas Piketty suggests that if it got to a stage where the top decile appropriated $90 \%$ of each year's output, revolution would likely occur unless some peculiarly effective repressive apparatus exists to keep it from happening. ${ }^{3}$ Even in terms of the system as it is, an inegalitarian spiral cannot continue indefinitely: Ultimately there will be no place to invest the savings, and the global return on capital will fall, until an equilibrium distribution emerges. ${ }^{4}$

The second of our four horsemen is resource depletion, which includes uranium, copper, phosphorus, rare earths which are vital for renewable energy, top soil, but above all water. Sixty per cent of fresh water is found in just nine countries. ${ }^{5}$ It is estimated that within twenty years almost half the world's population will experience water scarcity. Global consumption of water is doubling every twenty years, more than twice the rate of human population growth. Agriculture accounts for sixty five per cent (one ton of wheat requires one thousand tons of water), domestic use ten percent, and industry accounts for the rest. Even now 'the water table in major grain producing areas in China is falling at the rate of five feet per year. Of China's 617 cities 300 already face water shortages. $80 \%$ of their rivers no longer support fish life.' (Kunstler 2006).

Some analysts have been predicting peak oil for many years and if this were really the case it would have huge implications for farming and therefore for the capacity to feed seven or eleven billion. However, as Emmott notes, new reserves of oil and gas are constantly being found, and shale oil and gas is coming on stream. The problem, as he puts it, is not that there are not enough fossil fuels, but, to the contrary, that we will seek to use every last drop. ${ }^{6}$

The third horseman is the loss of biodiversity, which could lead to a crash of the whole eco system which sustains life. The history of evolution has seen a background rate of extinction of three species per year but this has now risen to one thousand species per year. Both in the oceans, with plankton, and on earth, with insects, the basis of the food chain is threatened. In places $70 \%$ of insect life has been lost. This is partly due to the widespread development of agricultural monocultures, and the use of toxic chemicals on plants, but also to global warming as species fail to adapt to changing temperatures. Loss of phytoplankton is particularly serious. This is responsible for around $60 \%$ of our oxygen, but warming seas are destroying it. If present trends continue it is predicted that oxygen depletion will mean that we will all effectively be living in the kind of atmosphere we associate with the summit of Everest (Sekerci and Petrovskii 2018).

The last of the horsemen is climate change. According to the Intergovernmental Panel on Climate Change (IPCC) the present carbon dioxide concentration has not been exceeded during the past four hundred and twenty thousand years and probably not during the past twenty million years. Currently we are adding six billion tons of carbon to the atmosphere each year. All life on earth, and not just human life, thrives within a relatively narrow temperature band. The addition of just one degree may dramatically raise the level of species extinction, and a few degrees could lead to irreversible damage. The mass extinction of the end Permian age was associated with a rise of $6{ }^{\circ} \mathrm{C}$ which is within the range of what both the IPCC and the Chief Economist of the International Energy Authority consider possible (Lynas 2007). Temperatures do not rise in a linear fashion but are likely to be accompanied by feedbacks and further temperature rises. Scientists at the Tyndal Centre in Manchester, UK, have

2 Today in France the richest $10 \%$ command $62 \%$ of total wealth while the poorest $50 \%$ have only $4 \%$. In the United States the most recent survey indicates the top decile owns $70 \%$ of America's wealth, while the bottom half claimed only $2 \%$. (Piketty 2014).

$3 \quad$ Piketty Capital cit. 263.

$4 \quad$ Piketty Capital cit. 366.

5 Water sufficient countries are those which have more than one thousand seven hundred cubic metres per person. Between one thousand and one thousand seven hundred cubic metres there is water stress and below one thousand cubic metres there is water scarcity.

6 (Emmott 2013) Ten Billion. cit. 76. 
argued that there is little to no chance of maintaining the rise in global mean surface temperature at below $2{ }^{\circ} \mathrm{C}$, despite repeated high-level statements to the contrary. Avoiding dangerous (and even extremely dangerous) climate change is no longer compatible with economic prosperity, they argue. To avoid such change the world would need "a planned economic contraction ... whilst allowing time for the almost complete penetration of all economic sectors with zero or very low carbon technologies" (Anderson and Bows 2011, p. 41). To contain world temperature rise at $4{ }^{\circ} \mathrm{C}$, they argued in 2011, emissions would need to peak by 2020 , which would require a reduction of around $3.5 \%$ per annum in $\mathrm{CO} 2$ from energy. By the time you read this, that goal will have been passed, and very little has been done. Even peaking at $4{ }^{\circ} \mathrm{C}$ will mean up to $40 \%$ reduction in maize and rice as the population heads towards 9 billion by 2050, so famine may be a consequence. As it is, in 2016 the Arctic Council already charted temperatures $20^{\circ} \mathrm{C}$ above the norm and highlights nineteen aspects of regime change, all of which may lead to tipping points which affect the world as a whole (Arctic Council 2016). In fact, Kevin Anderson argues, $4^{\circ}$ of warming is incompatible with the continuance of an equitable and civilised global community and he is clearly worried that $4^{\circ}$ might not be the end of it but that a rise of $6^{\circ}$ might occur (Anderson 2012). In October 2019 The UN Climate Gap report noted that countries were planning to extract more than twice the amount of fossil fuels from the ground than can be burned by 2030 if a $1.5^{\circ} \mathrm{C}$ target was to be met. Greenhouse gas levels continue to rise. ${ }^{7}$

The political context of these problems is a rising tide of narrow nationalisms around the world, twenty-first century weaponry put together with atavistic political, and often theopolitical, ideologies. Nearly half of the world's countries are not democracies, including the world's most populous state, China, and many exclude women from the vote (Lijphart 2012). Even those which are democracies are better regarded as pseudo-democracies, as corporate wealth and media power constantly skew election results, and the reservations Plato and Aristotle felt about democracy are vindicated by the rise of populism around the world.

The ideological context includes a great deal of denial at all levels, perhaps best instantiated by Steven Pinker's Enlightenment Now which appeals to statistical data to show that everything is getting better and argues that geo sciences will fix the problems of climate change (Steven 2018). The only rational response, from his point of view, is to continue the Enlightenment project more energetically than ever.

Pinker is a professor of psychology and a popular science writer. Many natural scientists, by contrast, including James Hansen, former chief climate scientist for NASA, Kevin Anderson, of the Tyndal centre in Manchester, UK, and marine biologist Sally Chisholm, are all sceptical of the possibility of technical fixes. ${ }^{8}$ They agree with James Kunstler that 'The idea of buying time until the tech demigods deliver a technology miracle is just another way of describing a cargo cult'. 9

Pinker's book has been lauded in the United States, and we may suspect that this is because its message is essentially that of George Bush in 1992, that the American way of life is not negotiable. 'Limits' are for losers. We can have our cake and eat it.

What chance is there, then, that the problems posed by the four horsemen can be addressed? Any response will be at the same time spiritual, cultural and political (and I include economics with politics).

\section{The Logic of Salvation}

The need to include all of these dimensions was recognised more than thirty years ago by Rudolf Bahro in his'Logik der Rettung. Wer kann die Apokalypse aufhalten?' (translated into English as Avoiding Social and Ecological Disaster).

\footnotetext{
https://wedocs.unep.org/bitstream/handle/20.500.11822/30797/EGR2019.pdf?sequence=1\&isAllowed=y. (Hansen 2009; Anderson 2012). Sally Chisholm quoted in (Klein 2014).

Kunstler Long Emergency 129 Cf.
} 
Bahro was a deviant Marxist (expelled from East Germany, after being imprisoned for writing The Alternative in Eastern Europe, in 1979), and a heretical Green, who left the German Green Party because of its compromises with the market system.

He argued three things. First, he believed that the ecological crisis was above all a spiritual problem, the manifestation of a 'sickness of the human spirit, of our collective psychodynamics' (Bahro 1994, German version 1987). Not a Christian or a conventionally religious person Bahro nevertheless believed that it was crucial to take up once again the idea of God. 'The last chance for our existence and emancipation lies in our being able to free ourselves from the patterns of the old culture, and to risk again and appeal to the godhead' (Bahro 1994, p. 304). It was the last chance because 'No order can save us which simply limits the excesses of our greed. Only spiritual mastery of the greed itself can help us. It is perhaps only the prophets and buddhas, whether or not their answers were perfect, who have at least put the question radically enough' (Bahro 1994, p. 25). The logic of self destruction, he argued-in line with the prophets and the Messianic Writings-lay in the human heart.

He pointed out (before Jared Diamond made the idea familiar) that human beings had repeatedly destroyed the ecosystems which supported them, but the power to do this had expanded exponentially with the coming of industrial society. At the root of the present problem, he argued, was capitalism, which makes money, a means of power resting on the principle of expansion to infinity, central to society. He took the term 'Megamachine' from Lewis Mumford to talk about the organisation of society around life without limits. This organisation of society structures human consciousness in violent and oppressive ways and underlies the whole technological and economic global culture. This analysis is close to Paul Ricouer's and Walter Wink's account of 'the Powers' which thrive on a spirituality of violence and hierarchy and threaten the world with destruction.

Bahro argued that a logic of salvation could not begin by trying to reform the present system. He looked for the growth of a new spiritual consciousness around the world, a jump in the evolution of the human spirit which had already started in the axial age of Buddha, Lao tzu, Plato, Christ and Mohammed (Bahro 1994, p. 65). It would take the form of an 'invisible church' which would be organised in small communities, which he had earlier likened to Benedictine communities (Bahro 1986). A new spiritual authority would form, existing as a horizontal, multilateral network, forbidding all direct or indirect constitution as a commanding social or political power (Bahro 1994, p. 228).

Second, Bahro denied that it was possible to pick and choose between the good and bad outcomes of industrial society.

Life cannot stand the basic load that industry lays upon it. It is ultimately with the Mercedes and washing machine detergents that we do the damage, rather than with bombs, nuclear power stations and dioxin - these swords of Damocles that we have suspended above ourselves. A private dwelling full of comforts necessarily confirms the whole worldwide infrastructure-including the need for armaments, because in face of monstrous differences in standards it is a threatened luxury (Bahro 1994, p. 92).

What E. P. Thompson called 'exterminism', the attitude which led to the creation and proliferation of nuclear weapons and which threatened to destroy humanity, Bahro referred to industrial society as a whole. He believed it was impossible to 'green' existing society because 'Today large-scale production, together with conurbations and their infrastructures, will unavoidably put an end to us' (Bahro 1994, p. 23).

Third, Bahro argued that the political form which emerged from the new consciousness he hoped for would be a network of small states; the economic form would be a subsistence economy; the cultural form would be a lifestyle of voluntary simplicity, beginning with people living 'in nodal points of communitarian life' (Bahro 1994, p. 305).

Bahro was a prophet and he got a prophet's reward. These ideas provoked even more hostility that the alternative, though rather than imprisonment he faced ridicule. The right called him an eco fascist, and the left thought his arguments represented an atavistic retreat to a pre industrial world view, with all its plagues and miseries. 
To his three arguments we can say that to point to the spiritual origin of the global emergency is something shared by many analysts from many points of view. For all of its New Age overtones, Bahro's way of presenting it addresses the fact that the emergency affects everybody on earth, from every religion and none, and cannot be addressed (in my view) by pushing the technological lever to maximum.

The warning that we cannot pick and choose the bits of the industrial system we like- the least palatable of his arguments, since it conjures up a pre-industrial civilization-has to be taken seriously. If we reject it we have to show how industrial culture can be de-toxified, how we can, for example, keep modern medicine and dentistry without the rest of the rest of the culture in tow.

With regard to new political forms there are many groups seeking precisely what Bahro was calling for thirty years ago. They have no power, influence or money. Can they together bring about the immense changes that are needed? It is a tall order. I am going to ask whether ekklesia has anything to contribute to the 'logic of salvation'.

\section{Ekklesia}

Bahro did not believe that the ecological crisis was a 'Last chance for an established Christianity (Bahro 1994, p. 68).' He had every reason to be sceptical. As Wendell Berry comments in relation to economic thinking, organized Christianity exists as 'a respecter and comforter of profitable iniquities' (Berry 1992). The atheist Harold Laski used to point out that the Christian ethic had accommodated itself to slavery at its ugliest, to capitalism in its most ruthless form, to every war that has been waged since Constantine made Christianity the official religion of empire-and, we have to say, continues to do so. ${ }^{10}$ We can argue, however, that these developments traduce the original intention of ekklesia.

The word 'ekklesia', as we know, referred to the assembly of free citizens in Athens meeting to determine policy. In the Septuagint the word is used to translate 'quahal'. Originally the quahal was the tribal muster, especially in time of war. In Deuteronomy it refers to the gathering to affirm the covenant (Dt. 9:10; 10:4). In the Septuagint the political sense was not primary, but rather the fact that the people were gathered together by God.

The word ekklesia is only used twice in the gospels (Mt. 16.18,18.17) and it has often been suggested that these texts are interpolations. The heavy concentration of the word in the rest of the Messianic Writings seems to indicate that it was a post Easter phenomenon. ${ }^{11}$ The church, this usage suggests, derives from the resurrection and from Pentecost but at the same time, I want to argue, it could not have formed if it played no part in the vision of Jesus. That it did so is suggested by the Matthean texts. Once we recognise that ekklesia translates quahal we can see that these texts may indicate that Jesus did intend a symbolic nucleus of a revivified Israel. While he seems to have expected the renewal of creation very soon he also has a lot to say about community. His disciples are called with a command to follow on a hard and narrow way (Mk. 1:17, Mt. 7:14) which involves the denial of security (Mt 8:20). Nothing is promised this group except Jesus' cup and baptism (Mk 10:38). This demand is made not only of the disciples but of anyone who wishes to follow him: 'If anyone would come after me, let them deny themselves and take up their cross and follow me' (Mk. 8:34). Jesus sends out the twelve with nothing except a staff (Mk. 6:8); they are defenceless and unprotected like sheep among wolves (Mt. 10:16); they will be refused hospitality and slandered. They will receive the blow on the right cheek which expresses 'the greatest possible contempt and extreme abuse' (Jeremias 1971). Jesus' call is addressed to the poor, those who are persecuted (Mt. 5:10), the little ones (Mk. 9:42. Mt. 10:42, 18:10), the least (Mt. 25:40,45) or simple ones (Mt. 11:25 and par). We are reminded of Paul's description of the community in the first letter to the Christians in Corinth, which included 'very few wise, powerful

10 Cited in (Alinsky 1969).

11 'Ekklesia' occurs 114 times outside the gospels including 23 times in Acts and 46 times in Paul (including 22 times in 1 Corinthians). 
or of noble birth' (1 Cor 1:26). Jesus used the word 'slave' or 'servant' in a very fundamental way to describe the vocation both of himself and all his disciples (Mk. 10:45ff; Luke 22:25ff). If we ask what it means to be a member of the community then, according to Jesus, we have to reply that they are douloi, slaves. It is this emphasis Paul takes up in Philippians when he speaks of Christ taking the form of a slave and urges the community to have this mind amongst themselves (Phil. 2:5ff).

Moltmann proposes that the early Christian community chose to use the word ekklesia because it marked it out as a tertium genus between Jews and Gentiles, and distinguished it from both the popular, state and private religions (Moltmann 1977). Greek speakers must have asked themselves, however, about the kind of forum this particular ekklesia represented. What kind of gathering was it?

It was his reflection on the cross which led Paul to talk about the 'weakness' of God but, as we have seen, he went on from there to see analogies to that weakness in a community which contained no important or influential people and later, in relation to his own difficulties, understood that God's strength 'was made perfect in weakness' (2 Cor. 12.9). The cross, for Paul, re-defined the nature of God, and therefore his understanding of the manner in which God works. Bahro believed that there was an "implicit' or 'enfolded' Order, a body of natural law in the Cosmos and on our planet, and that this order extends into us as a basis of behavior (Bahro 1994, p. 12). This is a Stoic idea, and Paul shared it, but Paul re-interpreted it in the light of what he learned from the cross. Paul believed that 'strength' and 'wisdom' - which we can gloss today as the kind of technological confidence illustrated by Pinker-are self-destructive and that only the 'weakness' of God ultimately succeeds.

The group founded on this conviction about the ultimate nature of reality spread through the Roman empire at great speed, becoming the religion of empire after three hundred years. There were undoubtedly predisposing factors for this such as the increasing barbarian threat and the growing interest in mystery religions, but some of the church's success was due to its steadfastness under persecution, as Tertullian famously said, and to its practical care for its members. Though the church never lacked critics, many were undoubtedly impressed by the extraordinary nature of its diagnosis of human ills and their remedy, the seriousness of its concern and the sanctity of its life. The church 'conquered' not through force of arms but through testimony and example.

\section{Social Movements}

The Church in the first three centuries is best understood as a social movement. Throughout history, says Manuel Castells, such groups are the producers of new values and goals around which the institutions of society are transformed, creating new norms to organise social life (Castells 2012). Social movements are the sources of social change, he argues, and therefore of the constitution of society. ${ }^{12}$ Unlike Trades Unions, say, they do not represent just one segment of the population but seek to change society as a whole. David Graeber talks of a 'prefigurative politics' - the idea that the organizational form that an activist group takes should embody the kind of society we wish to create (Graeber 2013). This is what Bahro looked for in his new communities, and it is also precisely how Paul understood ekklesia as he set it out to the small and fractious group in Corinth (1 Cor. 12).

There is often a strong utopian dimension in social movements which means they are not limited to the selection of practical goals. Rather, it makes it possible to think of aims and objectives which the dominant culture tends to exclude from the outset, and thus movements disseminate concepts and perspectives which might otherwise have remained marginal (Della Porta and Diani 1999). Recent forms of collective action, Alberto Melucci argued, largely ignore the political system and generally display disinterest towards the idea of seizing power. 'It appears that the traditional goals of taking political power and gaining control over the state apparatus have given way to a desire for immediate control over the conditions of existence and to claims to independence from the system' (Melucci 1996).

12 Castells Networks 12. 
It may be that social movements stake out the territory of a pre-figurative politics. If we are to survive humanly, however, we have to move from the pre-figurative to the realised. Can social movements, and can ekklesia, help do this? There are a number of ways in which contemporary social movements do this. First, governments often create new institutions, such as departments and agencies, in response to activists' demands. Second, they spawn dedicated organizations that generally survive long after a movement's moment has passed. Third, they change the people who participate in them, educating first activists, and then the wider society. 'To paraphrase a famous scholar: Activists make history, but they do not make it just as they please. In fighting one political battle, they shape the conditions of the next one' (Meyer 2009). Social movements may become institutionalised, but if so, says Sidney Tarrow, they will nevertheless have changed the terrain and helped to prepare the ground for something better (Tarrow 2011).

The change wrought by social movements, and by ekklesia as a social movement, are an example of strength through weakness. Social movements do not rely on big money or propaganda, let alone on armies. They spread by infection and example. 'A social revolution becomes political when it reaches a critical threshold of acceptance; this in fact did happen to the Roman Empire as the Christian church overcame it from below' (Wink 1992).

Social movements can of course be co-opted, as ekklesia was after Constantine's conversion, when it was swallowed whole by empire and began the litany of betrayal which Laski catalogues. How do we get from structures of power which destroy life-the 'Megamachine'-to structures which enable it? (the same question which the Deuteronomists asked, but in a much more complex world). How do we challenge the current wave of 'strong' men, the contemporary Caesars, (Putin, Trump, Xi Jinping, Erdogan, Modi etc.) whose strength Paul says is really weakness? More difficult still, how do we address the consumerism which holds us all in thrall?

\section{Confession and Community}

The move from the prefigurative to the realised is fragmentarily represented here and there-and it could not be otherwise. The social world is semper reformanda: No sooner does it become hegemonic than it needs critique and re- (rather than de-) construction (Veerkamp 2012). Václav Havel, like Bahro, looked to an 'existential revolution'-'a new experience of being, a renewed rootedness in the universe, a newly grasped sense of 'higher responsibility" (Havel 2015). These aspirations might sound vague, but they are the aspirations of millions of people seeking political and social alternatives across the planet. If there is a struggle, as Naomi Klein puts it, of 'capitalism vs the planet', then there are also all over the place (we cannot yet say confidently 'all over the world') social movements and people's organisations against the corporate takeover of life and in favour of lifestyles and social and political practices which will address the threats of the four horsemen. There are movements against industrial agriculture (Via Campesina), movements protesting 'business as usual' (Extinction Rebellion, Youth Strike), movements seeking a new paradigm for community life (Transition). Where does ekklesia stand in relation to this, or where should it stand?

First off, ekklesia needs to adopt the global emergency as a confessional issue, as the German Protestants identified Nazism's racial policies, and as the South African churches identified apartheid. A confessional issue is something which touches the very heart of what it means to be church. Apartheid and the Aryan clause both called in question the claim that salvation is for all equally. Bonhoeffer argued that a confession like Barmen is "the decision of the church based upon its entire doctrine, to take up the struggle at a particular place."13 Confession begins with an acknowledgement of guilt or complicity, with a call to the church to repentance, not the exclusion of others (Barth 1986). The global emergency is a confessional issue for at least three reasons: The unity of ekklesia is broken by the division between those who are the immediate victims of climate change, such as the Pacific

13 (Bonhoeffer 1966, p. 83) My italics. 
islanders, and those which are the main drivers, like the inhabitants of Europe and North America. Beyond this, coming generations and possibly all life are threatened by our drive for growth at every level. Effectively our commitment to growth at any cost amounts to an Aryan clause against our grandchildren and their grandchildren. Second, the neo-liberal economic model threatens to destroy many aspects of God's good creation. It is an anti-grace reality. Third, because it represents the subjugation of the human being and of human life to a product of human labour it is a form of idolatry. Death is the hallmark of every idol (Hinkelammert 1983).

If the global emergency is adopted as a confessional issue then, as the Lutheran World Federation in 1977 noted, 'Confessional subscription is more than a formal acknowledgement of doctrine. Churches which have signed the confessions of the church thereby commit themselves to show through their daily witness and service that the gospel has empowered them to live as people of God' (Duchrow 1986, p. 47). Not to follow faith with obedience is, as Luther said, to abolish Christ by preaching him'.14

Daily witness and service would mean, for example, carbon accounting as a normal rule of Christian discipleship, resolute opposition to neo-liberalism by any church signed up to the confession, and commitment to alternative forms of economy (as, for example, set out by Herman Daly, from a Christian standpoint, for the past fifty years). This would involve examining ekklesia's complicity with, and reliance on, the present financial system. A church which embraces Mammon cannot witness against it. For the sake of God's creation the church has to set its own financial house in order and develop different investment and economic strategies.

Because the global emergency threatens all human beings there is no room for ekklesia to take over the issue, and regard itself as riding to the rescue on a white charger. Nothing could be more ridiculous. A common translation of 'agape' is 'solidarity'. Ekklesia needs to stand in solidarity with Extinction Rebellion, Via Campesina and all the other groups, in friendly and respectful acknowledgment of their witness. It seeks a new economics and a new politics, a new façon de vivre, alongside everybody else who is doing this, emphatically not with the lunatic, and immoral, idea that such solidarity is in aid of a secret proselytization (immoral because it fails to respect the other).

However, what about Bahro's conviction that a return to 'God' is the heart of the 'logic of salvation'? Of course, ekklesia would cease to be if it ceased to worship the NAME, if it ceased to read its scriptures as the source of its identity and hope. In the course of the common struggle to birth a new and sustainable world there is plenty of time for friendly conversations about what we mean by 'God', and how it might be appropriate to worship God. Disciples of Jesus Christ will point to faith in cross and resurrection as the source of their courage and hope. As in the first centuries, such pointing ('witnessing') arises in response to friendly queries about what on earth it is which keeps one going. Following Paul, Christians claim that the logic of salvation is intrinsically bound up with the 'weakness of God', with the account of God visible in the cross, which is to say an account of God which is inconsistent with any form of crusading but is known in service and, following Bonhoeffer's account of the gospel, 'life for others'.

In 1923 the great Roman historian and philosopher, R.G. Collingwood, ended his book on Roman Britain by invoking 'the saints and scholars of Ireland and Iona, who lit the lamps of religion and learning in so many places during the Dark Ages' (Collingwood 1923). I suspect this widely read book may be the origin of both the conclusion to Alasdair McIntyre's After Virtue, and of Rosemary Sutcliff's marvellous novel about Dark Age Britain, The Lantern Bearers, likewise about the Christian contribution to the Dark Ages (Sutcliff 1959). MacIntyre argued that the important thing was the construction of local forms of community 'within which civility and the intellectual and moral life can be sustained through the new dark ages which are already upon us'. He added: 'If the tradition of the virtues was able to survive the horrors of the last dark ages, we are not entirely without grounds for hope' (MacIntyre 1985). Quite independently Bahro agreed. Together they point in the direction

14 (Bonhoeffer 1966, p.30) Letters. 
ekklesia should be moving — with the utmost urgency—in the present emergency. The confessional practice I have outlined could be part of a 'logic of salvation'.

Funding: This research received no external funding.

Conflicts of Interest: The author declares no conflict of interest.

\section{References}

Alinsky, Saul. 1969. Reveille for Radicals. New York: Vintage.

Anderson, K. 2012. Real Clothes for the Emperor: Facing the Challenges of Climate Change. Manchester: Tyndall Centre. Anderson, Kevin, and Alice Bows. 2011. Beyond 'dangerous' climate change: Emission scenarios for a new world. Philosophical Transactions of the Royal Society 369: 20-44. [CrossRef] [PubMed]

Arctic Council. 2016. The Arctic Resilience Report. Stockholm: Stockholm Environment Institute and the Stockholm Resilience Centre.

Bahro, Rudolf. 1986. Dare to form Communes. In Building the Green Movement. London: GMP Publishers.

Bahro, Rudolf. 1994. Avoiding Social and Ecological Disaster: The Politics of World Transformation. Bath: Gateway.

Barth, Karl. 1986. Die Theologie und die Mission in der Gegenwart. In Theologische Fragen und Antworten. Zurich: Theologischer Verlag.

Berry, Wendell, ed. 1992. Christianity and the survival of creation. In Sex, Economy, Freedom and Community. New York: Pantheon.

Bonhoeffer, Dietrich. 1966. The Way to Freedom. London: Collins.

Castells, Manuel. 2012. Networks of Outrage and Hope: Social Movements in the Internet Age. Cambridge: Polity.

Collingwood, Robin G. 1923. Roman Britain. Oxford: OUP.

Della Porta, Donatella, and Mario Diani. 1999. Social Movements; An Introduction. Oxford: Blackwell.

Duchrow, Ulrich. 1986. The Global Economy: A Confessional Issue for the Churches? Geneva: WCC, p. 47.

Emmott, Stephen. 2013. 10 Billion. London: Penguin, pp. 187-89.

Gorringe, Tim. 2018. The World Made Otherwise. Eugene: Wipf and Stock.

Graeber, David. 2013. The Democracy Project: A History, A Crisis, A Movement. London: Allen Lane.

Hansen, James. 2009. Storms of My Grandchildren: The Truth about the Coming Climate Catastrophe and Our Last Chance to Save Humanity. London: Bloomsbury.

Havel, Václav. 2015. The Power of the Powerless. London: Routledge.

Hinkelammert, Franz. 1983. The Economic Roots of Idolatry. In The Idols of Death and the God of Life. Edited by Pablo Richard. Maryknoll: Orbis, pp. 165-93.

Jeremias, Joachim. 1971. New Testament Theology. London: SCM.

Klein, Naomi. 2014. This Changes Everything: Capitalism vs. the Climate. London: Penguin.

Kunstler, James Howard. 2006. The Long Emergency. London: Atlantic Books.

Lijphart, Arend. 2012. Patterns of Democracy: Government Forms and Performance in Thirty Six Countries, 2nd ed.New Haven: Yale.

Lynas, Mark. 2007. Six Degrees. London: Fourth Estate.

MacIntyre, Alasdair. 1985. After Virtue: A Study in Moral Theory, 2nd ed. London: Duckworth.

Melucci, Alberto. 1996. Challenging Codes: Collective Action in the Information Age. Cambridge: Cambridge University Press.

Meyer, David. 2009. How Social Movements Matter. In The Social Movements Reader: Cases and Concepts. Edited by Jeff Goodwin and James Jasper. Oxford: Blackwell, pp. 417-22.

Moltmann, Jürgen. 1977. The Church in the Power of the Spirit. London: SCM.

Piketty, Thomas. 2014. Capital in the Twenty-First Century. Cambridge: Harvard.

Sekerci, Yadigar, and Sergei Petrovskii. 2018. Global Warming Can Lead to Depletion of Oxygen by Disrupting Phytoplankton Photosynthesis: A Mathematical Modelling Approach. Geosciences 8: 201. [CrossRef]

Steven, Pinker. 2018. Enlightenment Now: The Case for Science, Reason, Humanism and Progress. London: Penguin. Sutcliff, Rosemary. 1959. The Lantern Bearers. Oxford: OUP.

Tarrow, Sidney. 2011. Power in Movement: Social Movements and Contentious Politics, 3rd ed. Cambridge: CUP. 
Veerkamp, Ton. 2012. Die Welt Anders. Berlin: Argument.

Wink, Walter. 1992. Engaging the Powers. Minneapolis: Fortess, p. 183.

(C) 2020 by the author. Licensee MDPI, Basel, Switzerland. This article is an open access article distributed under the terms and conditions of the Creative Commons Attribution (CC BY) license (http://creativecommons.org/licenses/by/4.0/). 